\title{
Implications of strategy in innovation in SMEs
}

\author{
Jessica Mendoza Moheno*, \\ Martín Aubert Hernández Calzada and \\ Blanca Cecilia Salazar Hernández
}

Universidad Autónoma del Estado de Hidalgo, Abasolo 600, Col. Centro, C.P. 42000,

Pachuca de Soto, Hidalgo, México

E-mail: jessica_mendoza@hotmail.com

E-mail: martin_hernandez@hotmail.com

E-mail: salazar.bc@gmail.com

*Corresponding author

\begin{abstract}
The aim of this research is to analyse the innovation carried out by micro, small and medium enterprises (MSMEs) in connection with their strategic profile, according to Miles and Snow's (1978) typology. The study gathered data from 373 MSMEs in Mexico in the state of Hidalgo. The results show that prospectors have a better technological position than analysers, defenders and reactors. Also, prospectors, who give greater importance to innovation made in products and services, make more innovation in products and services, as well as in management. However, all types of companies claim to place importance on innovation in these issues, including reactor enterprises.
\end{abstract}

Keywords: innovation; strategy; small business; environment; Mexico; Miles and Snow; technological position.

Reference to this paper should be made as follows: Mendoza Moheno, J., Hernández Calzada, M.A. and Salazar Hernández, B.C. (2014) 'Implications of strategy in innovation in SMEs', Int. J. Business Environment, Vol. 6, No. 2, pp.161-176.

Biographical notes: Jessica Mendoza Moheno is a full-time Professor at the Universidad Autónoma del Estado de Hidalgo and is also a Professor at the Instituto Tecnológico de Estudios Superiores de Monterrey. She served as the President of the Change and Development Processes chapter of the Academia de Ciencias Administrativas in Mexico. Her areas of research include family owned business, organisational culture and small business. She has published several scholarly articles and books.

Martín Aubert Hernández Calzada received his $\mathrm{PhD}$ degree at the Universidad de Salamanca. He is a full-time Professor at the Universidad Autónoma del Estado de Hidalgo and he is also a Professor at the Instituto Tecnológico de Estudios Superiores de Monterrey. He is the author of numerous articles and books, including themes like small business, family-owned business, organisational culture and competitiveness.

Blanca Cecilia Salazar Hernández received her Master in Business Administration from the Instituto Tecnológico y de Estudios Superiores de Monterrey. She is currently studying her $\mathrm{PhD}$ degree at the Universidad Nacional Autónoma de México. Her areas of research are organisational design, innovation and SMEs. She has also written about organisational structure. 


\section{Introduction}

The research of micro, small and medium sized enterprises (MSMEs) around the world has garnered special attention as a result of their peculiar characteristics, their relevance in employment generation and their impact in the economy of the different countries since they represent most of the companies.

Innovation plays a key role in the progress of nations and in the development of organisations and is considered an essential issue for competitiveness. Innovative firms are a requirement for dynamic and competitive economies (Madrid-Guijarro et al., 2009) in that innovation is seen as an essential factor for economic development and a critical element for companies who wish to remain competitive, especially in scenarios of quick technological change, shorter product life cycles and intensified competition (Henderson and Clark, 1990).

Despite the importance of innovation, not all companies care about conducting continuous innovation in areas such as products and services, production processes and management since, depending on their strategy, innovation is not always a priority.

Nowadays, firms need to worry about choosing a strategy that can help them adapt to their particular settings and generate technological advantages to achieve competitive success. In the literature, we find different types of strategies (Miles and Snow, 1978; Porter, 1980; Miller, 2001); however, the typology proposed by Miles and Snow (1978) seems to have more support and validation (Pittino and Visintin, 2009), and furthermore, it has been applied to research on small and medium sized enterprises (SMEs) (Pittino and Visintin, 2009; De Sarbo et al., 2005).

Most of the research related to innovation management has focused on large organisations (Terziovski, 2010). In recent years, there has been significant research in SMEs, but innovation has been poorly studied in these firms. However, while the research has looked into the strategies that make SMEs grow, there are hardly any papers in the literature that relate the strategy and innovation in these economic units.

Tan et al. (2009) mention the risk of testing theories of big enterprises to SMEs. It is important to do research that supports the creation of particular theories for SMEs, especially in technology and innovation. There is a need to determine for different disciplines and research theories what theories and research methods have been developed to test existing theories and create new ones used in SMEs.

From a sample of 373 MSMEs in the state of Hidalgo, Mexico, this study tries to analyse the innovation carried out by MSMEs in relation to their strategic profile according to Miles and Snow's (1978) typology. The contribution of this study is on how the strategy chosen by small businesses is related to innovation since there are almost no studies considering these two issues in these businesses as most of the research in innovation and strategy has been made in big enterprises. This paper is organised in five parts; the second section presents the theoretical framework underpinning this research, probing innovation and strategy; the third part describes the methodology used including the hypotheses to be tested. The results are presented in the fourth part. In the fifth section there is a discussion of the results and, finally, we present the conclusions reached. 


\section{Theoretical framework and research hypothesis}

Different authors have emphasised the importance to differ SMEs from big companies (Tan et al., 2009; Terziovski, 2010). Tan et al. (2009) state that during the past years, research has focused on the attributes that allow SMEs to grow, and their contribution to the economy, without considering the distinction of a small business from an entrepreneurial business. Terziovski (2010) emphasises the application of informal strategies in SMEs, while Bessant and Tidd (2007) state the need that SMEs have to formalise their structures and their systems in order to be more efficient.

\subsection{Innovation}

Ahlstrom (2010) states that the primary purpose of businesses should be to develop new and innovative products that will generate growth and provide significant benefits to the population and not just monetary earnings. Innovation is seen as a new knowledge proposes the creation or improvement of new products, services, technical or managerial processes in order to cover customers' needs and expectations (Afuah, 1999; Sanchez and Chaminade, 1996). This knowledge might be developed or adopted by an organisation, but it is only when applied to satisfy a specific need that it becomes innovation.

The Oslo Manual (2005) considers four types of innovation:

a product

b process

c management

d marketing.

The Organization for Economic Cooperation and Development's (OECD) concept encompasses a wide range of possible innovation: "innovation is the introduction of a new product (or service) or a significantly improved process, marketing method or a new managerial process in internal practices in the workplace organisation or external relations" [OECD, (2005), p.5]. Therefore, from this broad concept, it can be deduced that innovation can yield results in a tangible (product) or intangible way (process improvements, organisational practices, marketing of goods and services). Freeman (1974) points out that technological innovation refers to innovation in product changes or marketing of new products and innovation in manufacturing processes or the acquisition of new equipment. However, innovation also occurs in management, for instance, changes made in structure. Rouse and Daellenbach (2002) suggest that structure is one of the items that have an influence on innovation.

Currently, it is believed that big companies are the ones who have the financial resources to invest in the generation or purchase of innovation; however, SMEs have the ability to react to changes in demand. This means that it is their flexibility - an advantage due to their size - and their capability to collaborate with other firms through subcontracting and inter-business relations that make a better response to new schemes in industrial organisations possible (Dussel, 2001). Several studies on the generation of innovation, both in SMEs and big companies, have found no relationship between the 
firm's size and its availability to carry out innovation. This means that independent of the size, innovation can be made (Afuah, 1999).

Even though SMEs play an important role in the economic units and considering that innovation can be applied to any issue of a firm, it has been proven, through a study done in SMEs in the State of Hidalgo, that only one out of every three SMEs carries out innovation; $31 \%$ of the innovation is product-oriented, $32 \%$ goes to production processes, $22 \%$ to the product's logo, and $34 \%$ to general aspects of organisation (Saavedra et al., 2007). If we take into account that firms that do not evolve run the risk of extinction, SMEs must think about strategies that can help them survive and develop to assure their continuity in the marketplace.

On the other hand, Madrid-Guijarro et al. (2009) confirm that the ability to introduce innovation depends on the characteristics of small businesses, in such a way that a reduced bureaucracy, the owner's experience, and close contact among managers and customers could make its implementation easier.

It is believed that although the Oslo Manual is specifically designed for the business sector, innovation is present in all sectors, including the manufacturing industry and the primary and service sectors. Each sector represents an important issue to highlight because if we consider the statistics of MSMEs in Mexico, according to the 2003 Economic Census, they represent $99.2 \%$ of the total economic units in the country, $53 \%$ of which are concentrated in the business sector (INEGI, 2004).

Since a firm's size is not a feature of decision for innovation, nor is the sector to which it belongs, it is interesting to analys e the factors, both external and internal, that could influence the development and evolution of MSMEs.

\subsection{External factors}

According to Cohen and Levinthal (1990), there are three deciding factors for the investment in R\&D: demand, technological opportunity and the conditions for property. Taking this as a reference, different studies have been done to measure the influence that these innovation factors have on SMEs.

The research done by Arbussa et al. (2003) shows that firms in growing sectors are the ones who invest the most in R\&D. This was determined by contrasting the investment and the sales growth; that means that when firms are in high projection areas, it is more feasible to invest in innovation since their investment will assure them a profitable market.

Also, the technological opportunity established by the knowledge provided by customers, suppliers, universities, research centres and government organisations is a contributing factor for innovation. The industrial sectors that are backed up with external research promote the investment in R\&D. It is important to generate networks with different institutions (government investment, industrial research groups, and university research centres), to encourage the development of innovation in a specific sector since this can bring savings in internal expenses and the generation of interest from SMEs for innovation (De Sainte-Marie, 1999).

Property is another important factor for the development of innovation in businesses (Cohen and Levinthal, 1990); paradoxically, the diffusion of innovation can discourage the decision of doing innovation. In regards to patent registration, it is different and presents specific difficulties according to the sector; thus, we can see that there is a relationship between the amount of $\mathrm{R} \& \mathrm{D}$ and the use of patents by SMEs. However, 
when property creates barriers of entrance, due to the high level of innovation and because it cannot be easily copied, it encourages more investment (Arbussa et al., 2003).

Madrid-Guijarro et al. (2009) analysed 294 SMEs in Murcia, Spain, looking at barriers that prevent innovation, classifying them into internal (lack of financial resources, poor human resources, weak financial position, high costs and risks) and external (turmoil, lack of external sponsors, opportunities, lack of information and lack of support from the government). The results suggest that barriers have a differential impact on innovation in products, processes and management. The most significant barriers to innovation are associated with costs and to a lesser extent with resistance from management and employees.

On the other hand, Mendez (1999) has found external factors that hinder the generation of innovation in SMEs. These factors are associated with supply and demand and the environment in which these firms perform, as shown in Figure 1.

Figure 1 External factors that hinder innovation

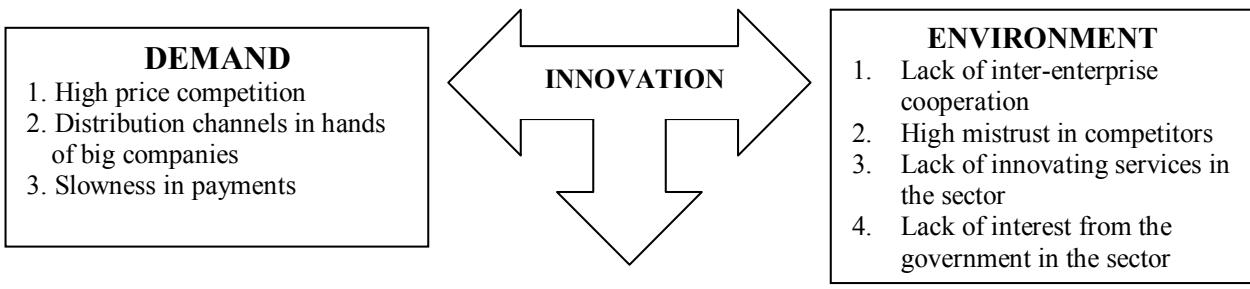

\section{SUPPLY}

1. Lack of financial mechanisms

2. Lack of qualified personnel

Source: Based on Mendez and Alonso (2002)

In regards to demand, Mendez and Alonso (2002) affirm that when SMEs are in aggressive sectors that compete with a price-cost strategy, the distribution channels are poorly controlled or are dominated by big corporations and customers become latepayers; then companies run the risk of trying to reduce costs using precarious or poorly qualified labour. This undoubtedly has an impact on the assignment of resources the firm can invest in innovation due to the limited availability of capital for the purchasing and development of innovation. Another issue that has an impact on the reduced availability of resources is the recruitment of highly qualified technicians who can bring new knowledge to the organisation.

Their particular environment has a significant influence on innovation. Without a doubt, the behaviour of the sector, shown through the actions of the heads of the companies, is of great relevance. This means that when they lack confidence or the working environment is of little cooperative tradition, the innovation created by interenterprise cooperation becomes limited (Mendez and Alonso, 2002). This is of great relevance since one of the strategies that SMEs can put into practice to generate innovation comes from cooperation networks among competitors, research centres and government agencies.

Supply ends up being a constraint for innovation in SMEs due to the lack of adequate funding which would be useful to encourage internal innovation or to purchase from 
others. Another aspect to consider is that even if the government presents financing programs for SMEs, it is complex to have access to those funds due to the limited information available to gather the documents required by the lending agencies (Alonso and Mendez, 2000). The studies reflected in the Oslo Manual (2005) suggest that finance is another crucial factor for the generation of innovation. Unfortunately, SMEs have little opportunity to obtain it, and when financial difficulties arise, the ability for innovation is hindered.

In addition, there is little or no credibility on behalf of employers in training as they cannot see the immediate use of the knowledge acquired and have no time for training courses, and this, undoubtedly, affects the business vision of SMEs' leaders (Mendez and Alonso, 2002).

We conclude that the type of industry and its projection affects the innovation culture of the members in the firms. Thus, the external factors that influence innovation in SMEs are the following: competitiveness sector, high disposition for intervention from other organisations and the interest from other businesses in the generation of innovation.

\subsection{Internal factors}

From an analysis of the literature (Sanchez and Chaminade, 1996; Alonso and Mendez, 2000; Arbussa et al., 2003; Foreman-Peck et al., 2006; Salazar et al., 2006; Saa and Diaz, 2007), we can determine in a very general way the factors that affect organisational innovation, centred in the capability that organisations have to create and transmit information and develop their human capital, their flexibility for adopting new forms of management, readiness for intervention and disposition to absorb new knowledge, among others. Table 1 summarises the internal factors that affect innovation.

Table 1 Internal factors which affect innovation

\begin{tabular}{|c|c|c|}
\hline Factor & Description & Author \\
\hline $\begin{array}{l}\text { Capability to generate } \\
\text { financial information }\end{array}$ & $\begin{array}{l}\text { Limit the awareness of the } \\
\text { economic aspects that are affected } \\
\text { by knowledge, which in turn is } \\
\text { reflected in the potential for } \\
\text { innovation }\end{array}$ & $\begin{array}{c}\text { Sanchez and Chaminade } \\
\text { (1996) }\end{array}$ \\
\hline $\begin{array}{l}\text { Changes in management, } \\
\text { direction, and organisation of } \\
\text { production }\end{array}$ & $\begin{array}{l}\text { When these are made, they } \\
\text { become a pre-condition for } \\
\text { technological innovation }\end{array}$ & $\begin{array}{c}\text { Sanchez and Chaminade } \\
\text { (1996); Oslo Manual } \\
(2005)\end{array}$ \\
\hline $\begin{array}{l}\text { Talent management or } \\
\text { brainpower }\end{array}$ & $\begin{array}{l}\text { Personnel training according to } \\
\text { the objectives of the organisation. } \\
\text { It involves the ability to locate, } \\
\text { develop and utilise the talents of } \\
\text { employees }\end{array}$ & $\begin{array}{l}\text { Sanchez and Chaminade } \\
\text { (1996); Oslo Manual } \\
\text { (2005); Salazar et al. } \\
\text { (2006); Saa and Diaz } \\
\text { (2007) }\end{array}$ \\
\hline Investment capability & $\begin{array}{l}\text { Resources available for the } \\
\text { purchase or development of } \\
\text { technology. }\end{array}$ & Arbussa et al. (2003) \\
\hline $\begin{array}{l}\text { Capability to absorb new } \\
\text { technology and knowledge }\end{array}$ & $\begin{array}{l}\text { Knowledge of the technology } \\
\text { available and of the organisation's } \\
\text { structure, which will allow the } \\
\text { incorporation of it in the } \\
\text { production processes. }\end{array}$ & $\begin{array}{l}\text { Arbussa et al. (2003); } \\
\text { Saa and Diaz (2007) }\end{array}$ \\
\hline
\end{tabular}


Table 1 Internal factors which affect innovation (continued)

\begin{tabular}{|c|c|c|}
\hline Factor & Description & Author \\
\hline $\begin{array}{l}\text { Capability to absorb new } \\
\text { technology and } \\
\text { knowledge }\end{array}$ & $\begin{array}{c}\text { It involves the ability of the } \\
\text { organisation to recognise, assimilate, } \\
\text { integrate and exploit new knowledge, } \\
\text { which stems from the recognition of } \\
\text { the value of it. }\end{array}$ & \\
\hline Business strategy & $\begin{array}{l}\text { Investment in human development, } \\
\text { quality management and policies to } \\
\text { guide customers. }\end{array}$ & $\begin{array}{l}\text { Foreman-Peck et al. } \\
\qquad(2006)\end{array}$ \\
\hline Information networks & $\begin{array}{c}\text { Create, document and communicate } \\
\text { valuable information internally and } \\
\text { externally. }\end{array}$ & $\begin{array}{l}\text { Foreman-Peck et al. } \\
\qquad(2006)\end{array}$ \\
\hline $\begin{array}{l}\text { Use of external } \\
\text { knowledge }\end{array}$ & $\begin{array}{l}\text { Involves the ability of organisations to } \\
\text { identify, locate, acquire and assimilate } \\
\text { external knowledge. Strategy: } \\
\text { Learning by hiring. }\end{array}$ & Saa and Diaz (2007) \\
\hline Ability to relate to others & $\begin{array}{l}\text { When organisations are willing to } \\
\text { work collaboratively with other } \\
\text { organisations as well as share and } \\
\text { transfer knowledge. }\end{array}$ & $\begin{array}{l}\text { Foreman-Peck et al. } \\
\text { (2006); Saa and Diaz } \\
\text { (2007) }\end{array}$ \\
\hline Protection of knowledge & $\begin{array}{l}\text { Be able to protect knowledge from } \\
\text { expropriation and imitation of } \\
\text { competitors. }\end{array}$ & Saa and Diaz (2007) \\
\hline $\begin{array}{l}\text { Time committed to } \\
\text { training by entrepreneurs }\end{array}$ & $\begin{array}{l}\text { Availability and credibility of } \\
\text { employers in training, where they } \\
\text { value the usefulness of it. }\end{array}$ & $\begin{array}{c}\text { Alonso and Mendez } \\
(2000)\end{array}$ \\
\hline $\begin{array}{l}\text { Direct contact with the } \\
\text { end market }\end{array}$ & $\begin{array}{l}\text { When the organisation has reliable } \\
\text { knowledge of the market needs, people } \\
\text { are encouraged to generate innovation }\end{array}$ & $\begin{array}{c}\text { Alonso and Mendez } \\
(2000)\end{array}$ \\
\hline
\end{tabular}

All these factors can contribute to innovation, even though managers are not always aware of it. In summary, it is the entrepreneurial culture that could ultimately help in opening SMEs to external knowledge as well as a good attitude toward the generation, documentation, and transmission of information that would help to strengthen innovation, which would result in the generation of business competitiveness.

\subsection{Strategy}

In recent years, organisational strategy has taken a special interest in research due to the environment's external influence on firms (Gomez-Mejia et al., 1996), which has made entrepreneurs begin to look at research as a way of taking competitive positions in global markets of high technology and a service-based economy (Miles and Snow, 1978).

Porter (1980) suggests that business strategic planning should be aligned to the environment, which means that strategy is an adaptive mechanism to the environment. Thus, environment is an external factor that directly affects the firm and its strategy; therefore, it is necessary to continuously take into account that strategy does not remain static but enjoys a great flexibility. 
Innovation is a resource that could generate competitive advantages. Prahalad and Hamel (1990) affirm that the real advantage resources have is the capability of executives to consolidate technologies and create new competences for the benefit of their firms. Jonash and Somerlatte (1990) state that innovative enterprises have greater profits than those with a lesser degree of innovation or those who do not innovate at all. Consequently, technology today occupies a special place in the research agenda. Lawlor and Kavanagh (2009) state that technology is not only a significant input, but it is the significant input for competitiveness.

Several authors have argued that strategic planning leads to better performance and gives support to innovation (Estrada et al., 2011). Barrand and Goy (2005) state that SMEs carry out informal planning. A study made in Mexico showed that only $38 \%$ of SMEs have a written strategic plan (Saavedra et al., 2007) and the period of time of their plan is only one year. SMEs give little importance to planning their activities and establishing a strategy that would help them reach their goals.

Different authors have proposed typologies of strategy (Miles and Snow, 1978; Porter, 1980; Kotler et al., 2001). However, in this research we will focus on the typology proposed by Miles and Snow (1980), which, according to several authors (Hambrick, 2003; Pittino and Visintin, 2009), has been considered the best type of strategy since it offers the most appropriate description of the guidelines to innovation and change.

The typology developed by Miles and Snow (1978) is based in the strategic behaviour that companies follow, and it proposes four types of companies that are next described:

a Defenders - Directors have high experience within their limited area of operation, but they tend outside their firms to look for opportunities of new products. As a result, they very seldom make big changes in their technology, structure or methods of operation. Instead, they put their efforts in improving the efficiency of their existing operations. The characteristics of defenders are a limited line of products, a working structure and abilities focused on efficiency in production, process engineering and cost control. They tend to ignore changes that do not directly impact their field and usually are not at the forefront of new products, services and markets. With regard to management, they focus on a centralised type of control, with a common pattern of mechanised organisation. The flow of instruction goes top-down, and the system is somewhat bureaucratic with excessive paperwork, which denotes control. Normally, they stay within their existing stable fields and market niches. The development of new products for these firms is limited to improving the already existing products. Efficiency and control are important factors for businesses, and they are more formal and centralised than prospectors. They try to find profitability by keeping their existing products in stable markets through technological efficiency and tend to ignore external development.

b Prospectors - They continuously search for new market opportunities and recurrently experiment with potential answers to emerging environmental trends. These organisations are usually creators of change and of the uncertainty to which their competitors must respond. One of their characteristics is to make changes in their products with relative frequency. However, due to their strong concern for product and market innovation, these organisations are often not completely efficient. Their organisation's growth and development can be fatal when trying to 
make a dimensional jump. The characteristics of prospectors include a varied product line, multiple technologies, a structure divided by product and geographically, market research and engineering development. Their personnel often receive better incomes than in defender enterprises. They are the most innovative type of businesses and emphasise the development of new products and technologies, as well as the exploring of new markets. They try to be the first in the market to offer new products and continuously experiment with answers to emerging trends and changes in the market. They are seen as firms with a low degree of formalisation, which make decisions in a decentralised way and have high flexibility. Prospectors continuously add new products and new markets to their portfolio and put a lot of effort in monitoring environmental conditions, trends and events. They focus on finding and exploiting new products and market opportunities.

c Analysers - They operate under two different product-market domains: one relatively stable and the other one changing. In their stable areas, these companies operate in a routine and efficient way through the use of formalised structures and processes. In their most innovative areas, key managers closely observe their competitors in search of new ideas and quickly adopt those that look most promising. The characteristics of analysers include a limited basic line of products; they find a reduced number of related products and/or market opportunities, cost efficient technology for stable products and technological projects for new products, mixed structure and abilities in productive efficiency, process engineering and marketing. They are rarely the first to enter new markets. They try to combine the exploring capability and innovation of prospectors with the defenders' ability to serve the markets effectively. These firms pursue efficiency in stable markets that they serve and try to adapt and prepare for change in turbulent markets where they are also active. However, they are not the first to take risks; their focus is on the prompt adoption of new concepts launched by successful prospectors. They imitate the best of the products and markets developed by prospectors.

d Reactors - They are those firms where there is an inconsistency in strategyenvironment, or where strategy, structure and process are poorly aligned. There is evidence that, except for highly regulated industries, reactors have a lower performance than the other three types. The staff at these firms is satisfied with their work.

This typology clearly shows the characteristics of each firm in relation with the type of structure, market behaviour, and the tendency towards innovation, according to the type of strategy each firm chooses to implement.

In the research done by Timens et al. (2006) in medium and large sized enterprises in Australia, Denmark and Norway, it was proven that the practices and reasons for improvement in new product development are not so different among prospectors, analysers and defenders because all three are under development, forced by competitors' changes, new technologies and management concepts.

In a study made in Dutch SMEs, De Jong (2011) found that the entrepreneurs' intention to carry out innovation processes is related to the power perceived by the buyer and the existing rivalry with other enterprises in the market even though the correlation with rivalry is significant only when firms have no strategic interest in innovation. 
Despite the fact that SMEs are different from big companies (Hudson et al., 2001; Tan et al., 2009), Terziovski (2010), through research on 600 Australian SMEs, found out that SMEs are similar to big companies in their strategic innovation, and the formal structure is their guide to performance even though they do not have an innovation culture.

There is an interesting point raised by Song et al. (2011). The authors analysed the conditions where strategic planning increases or decreases the number of projects to develop new products and the performance of the business through a sample of 227 firms. Empirical evidence suggests that more strategic planning and more projects to develop new products lead to better performance. However, research suggests that strategic planning decreases, rather than helps, the number of projects to develop new products; consequently, improvisation leads to the creation of ideas to develop projects, where innovations tend to materialise from improvised processes. The authors concluded that flexible strategic planning that makes room for potential improvisation is necessary in the management of new product development. This explains why big businesses with high levels of R\&D can overcome the negative effects of strategic planning.

The literature generally agrees that prospectors continuously search for new market opportunities and are the ones who are the most willing to invest in technology (Miles and Snow, 1978). Prospectors work to keep their reputation as innovators in products and the development of new markets (Dvir et al., 1993). Therefore, prospectors will have a better technological position than the rest of the firms. Based on this, we propose the next hypothesis:

H1 Prospectors tend to have a better technological position than analysers, defenders and reactors.

Kabanoff and Brown (2008) found that prospectors have the highest score in innovation in their knowledge structures. This means that innovation is not a priority for defenders and analysers. Dvir et al. (1993) state that defenders are more conservative in their investment in technology: they invest in new technologies only when they are convinced of their potential contribution to keep their competitive advantage. On the other hand, prospectors continuously scan technology more widely and look for new ideas and processes. According to Miles and Snow (1978), doing innovation is not always an easy decision, especially for analysers who tend not to move until a competitor makes a change, as well as defenders who react until they do not have an exit. Prospectors, however, continuously innovate in production processes, management and products and services.

H2 Prospectors tend to innovate more in production processes and management than analysers, defenders and reactors.

Singh and Sharma (2010) suggest that prospectors have intensive product planning and design systems. We believe that prospectors, since they are more interested in risk and able to invest in innovation, give more importance to innovation in operational processes, products and services and management than analysers, defenders and obviously reactors, since they care more about making innovation in all the issues, trying to become the first ones in the market.

H3 Prospectors give more importance to innovation in operational processes, products/services and management. 


\section{Research design}

The objective of this research is to analyse the innovation carried out by MSMEs according to Miles and Snow's (1978) strategic profile, through a sample of 373 micro, small and medium sized firms in the State of Hidalgo, Mexico. The distribution of the sample is shown in Table 2.

Table 2 Distribution of the sample

\begin{tabular}{lcc}
\hline Sector & Frequency & Percentage \\
\hline Agrobusiness & 12 & $3.21 \%$ \\
Manufacturing and traditional crafts industry & 74 & $19.84 \%$ \\
Construction & 25 & $6.70 \%$ \\
Commerce and trade & 141 & $37.80 \%$ \\
Tourism & 49 & $13.14 \%$ \\
Transportation and communications & 7 & $1.88 \%$ \\
Services & 65 & $17.43 \%$ \\
Total & 373 & $100 \%$ \\
\hline
\end{tabular}

The survey used was developed by Universidad de Cantabria, Universidad Tecnológica de Cartagena, and Universidad de Murcia, for strategic analysis and the development of micro, small and medium sized companies. This survey contains a section related to management which includes issues related to strategic planning and the strategy used by the firm, based on Miles and Snow's (1978) typology. It also has another section with questions related to technology and innovation done by the enterprise and the importance given to innovation in the production, product/service and management processes in a 5-type Likert scale. The survey was directed to owners or manager-owners.

\section{Results}

A total of 373 micro, small and medium sized businesses participated in the research, most of all in the trade and service sector (56.4\%), in the manufacturing industry $(16 \%)$ and the rest from different sectors. Most of the firms are family owned businesses $(76 \%)$, and since the majority control is in the hands of family members, also, the age of the firms is on average 16 years, and the number of employees varies from 5 to 90 , with an average of 25. The CEO's average age is 45 years, and $59.9 \%$ of them have a higher education.

The results show that $48.4 \%$ have a strategic plan, whereas $51.6 \%$ do not have a written plan. Related to time, most of the plans are made in the short term for a period of time of one year, representing $40.5 \%$, while only $29.5 \%$ are for a period longer than a year.

Concerning the type of strategy participants said to have, it was noted that $33.2 \%$ adopted a prospector type strategy, $36.6 \%$ had taken up an analyser type, $24.3 \%$ the defender type, and the remaining 5.9\% do not have a defined strategy, which places them in the reactor type strategy (Table 3 ). 
Table 3 Type of strategy adopted by businesses

\begin{tabular}{lc}
\hline Type of strategy & Percentage \\
\hline Prospector & $33.2 \%$ \\
Analyser & $36.6 \%$ \\
Defender & $24.3 \%$ \\
Reactor & $5.9 \%$ \\
\hline
\end{tabular}

Table 4 illustrates the values that participants believe to have in respect to the technological position they suppose they have in relation with their competitors. As hypothesised, prospectors have the best technological position; there are significant differences $(\mathrm{F}=13.853, \mathrm{p}=.000)$ showing that prospectors, followed by analysers, are the ones who believe they have a stronger technological position.

Table 4 Differences in technological position

\begin{tabular}{cccccc}
\hline & Prospector & Analyser & Defender & Reactor & Level of significance \\
\hline Technological position & $4.50 *$ & $4.12 *$ & $3.77^{*}$ & $3.71 *$ & .000 \\
\hline
\end{tabular}

Note: $* \mathrm{p}<0.05$

Table 5 Differences in innovation made in production processes, products/services and management

\begin{tabular}{lccc}
\hline Issues & Has done & Has not done & Total \\
\hline Innovation in production processes & & & \\
Prospector & $70.5 \%$ & $29.5 \%$ & $100 \%$ \\
Analyser & $62.4 \%$ & $37.6 \%$ & $100 \%$ \\
Defender & $62.6 \%$ & $37.4 \%$ & $100 \%$ \\
Reactor & $52.2 \%$ & $47.8 \%$ & $100 \%$ \\
$x^{2}=.244$ & & & \\
Innovation in products/services & & & \\
Prospector & $90.7 \%$ & $9.3 \%$ & $100 \%$ \\
Analyser & $82.2 \%$ & $17.8 \%$ & $100 \%$ \\
Defender & $74.7 \%$ & $25.3 \%$ & $100 \%$ \\
Reactor & $70.8 \%$ & $29.2 \%$ & $100 \%$ \\
$x^{2}=.005$ & & & \\
Innovation in management & & & \\
Prospector & $77.1 \%$ & $22.9 \%$ & $100 \%$ \\
Analyser & $74.5 \%$ & $25.5 \%$ & $100 \%$ \\
Defender & $57.6 \%$ & $42.4 \%$ & $100 \%$ \\
Reactor & $54.2 \%$ & $45.8 \%$ & $100 \%$ \\
$x^{2}=.002$ & & & \\
\hline
\end{tabular}

Table 5 shows the issues where innovations were made in the last two years, either in production processes, products and services or management, showing that most innovations were made in products and services. With regard to innovation in production 
processes, prospectors made further innovations in production processes, followed by defenders, analysers and reactors although there are no significant differences. Innovation to products and services are most frequently made by prospectors and analysers, with important differences $\left(x^{2}=.005\right)$. In the innovation oriented to management, there are also major differences $\left(\mathrm{x}^{2}=.002\right)$, where prospectors do most of the innovation. Therefore, our second hypothesis is partly accepted since prospectors are the ones who tend to innovate more in products and services and in management, and even though prospectors are the ones who do more innovation in production processes, no significant differences were found.

On the other hand, managers were asked to point out the importance given to production processes, to products/services and to management on a scale from 1 to 5 . As presented in Table 6, firms believe that innovation in all areas is important, finding significant differences $(\mathrm{F}=9,873, \mathrm{p}=.004)$ between prospectors and defenders in the importance given to products and services. With regard to the importance that respondents give to innovation in production processes and management, we found no significant differences. Therefore, our hypothesis 3 , which stated that prospectors tend to give to a greater extent more importance to innovation in production processes, in products and services and in management, is only partially accepted since there were significant differences only in the importance that firms give to innovation in products and services.

Table 6 Differences in the importance given to innovation

\begin{tabular}{lccccc}
\hline Issues & Prospector & Analyser & Defender & Reactor & Level of significance \\
\hline $\begin{array}{l}\text { Importance given to } \\
\text { innovation in production } \\
\text { processes }\end{array}$ & 4.59 & 4.49 & 4.41 & 4.42 & .460 \\
$\begin{array}{l}\text { Importance given to } \\
\text { innovation in } \\
\text { products/services }\end{array}$ & $4.66^{*}$ & 4.51 & $4.30^{*}$ & 4.25 & .004 \\
$\begin{array}{l}\text { Importance given to } \\
\text { innovation in } \\
\text { management }\end{array}$ & 4.48 & 4.34 & 4.46 & 4.08 & .174 \\
\hline
\end{tabular}

Note: ${ }^{*} \mathrm{p}<0.05$

\section{Discussion and conclusions}

The goal to analyse the innovation made by MSMEs according to their strategic profile, based on Miles and Snow's (1978) typology, was achieved. The results show that prospectors declare to have the strongest technological position, followed by analysers, defenders and, lastly, reactors. These results confirm that prospectors, since they take the most risks and are continuously looking for new opportunities, have the best technological position.

Prospectors tend to innovate to a greater extent in production processes, in products and services and in management, meaning this hypothesis is only partially accepted since there were significant differences only in the importance that firms give to innovation in products and services and the innovation made in management. This could be due to the fact that employers tend to innovate in issues that directly and immediately impact 
earnings, resulting in innovation in production processes, whereas innovation in products and services, as well as in management, is done less frequently because such innovation is not visible and its impact can only be seen in the long term, so analysers, defenders and reactors tend to do less innovation in these issues. In addition, the lack of significant differences in production processes may be due to the fact that most of the enterprises in the sample do trade and service activities.

It is interesting to observe that most of the MSMEs in Hidalgo see themselves as prospectors and analysers. The results are consistent with those from previous research (Pittino and Visintin, 2009; Miles and Snow, 1978), where prospectors are the most dynamic of the four kinds of firms. They tend to take risks in turbulent settings, which is why they are constantly innovating and exploring new markets. Defenders operate in stable environments and carry out continuous improvements in order to keep the efficiency of costs and high product quality, and analysers copy the innovation their competitors do, taking no risks.

In this study, we present empirical evidence that prospectors, followed by analysers, who believe they have a better technological position in comparison with their competitors and carry out more innovation in production, products/services and management processes. The same happens with the importance given to innovation in the issues mentioned before (production, product/services and management processes), where prospectors, followed by analysers and defenders, give respectively greater importance to it although significant differences are only in innovation in management.

This is consistent with Timens et al.'s (2006) results, where prospectors, analysers and defenders are not as different as expected since they all have the need to survive and front their competitor's dynamic competition, being obliged to invest in innovation.

Innovation seems to worry managers, even those who consider themselves reactors since despite not having a specific strategy, the results show they do care about innovation and try to improve their production processes, products, services and management. The results show no significant differences in the importance given to innovation in production processes and management, and only prospectors and defenders differ in the innovation done in products/services.

It is also important to mention the need by MSMEs to pay more attention to formal planning since the lack of it, as well as time limits, could result in poor performance.

We believe that our study might have some managerial implications. The identification of important characteristics of MSMEs in the State of Hidalgo could help in drawing up plans in agreement with the chosen strategy and to relate them with environmental and performance issues. The study may also have implications for the government in public politics matters developed for MSMEs for the planning of political decisions related to these organisations.

The main limitation of this study is that some of the firms involved may have been misclassified, given the fact that it was the owner who, based on his/her own perception, chose one of the options; thus, for future research, it will be necessary to design other surveys that might determine more clearly the type of strategy a firm is using. Also, most of the participating firms belong to the trade and services sector, and it is necessary to include firms from other sectors to get more consistent results that reflect the reality of companies in the region. Nevertheless, this research begins a new line of research to test the effects of innovation on performance of firms. 


\section{References}

Afauh, A. (1999) La dinámica de la innovación organizacional, El nuevo concepto para generar ventaja competitiva y rentabilidad, Oxford, University Press, México.

Ahlstrom, D. (2010) 'Innovation and growth: how business contributes to society', Academy of Management Perspectives, August, Vol. 24, No. 3, pp.11-24.

Alonso, J.L. and Méndez, R. (2000) Innovación, pequeñas empresas y desarrollo local en España, Civitas Ediciones, S.L., Madrid, España.

Arbusaá, A., Bikfalvi, A. and Valls, J. (2004) La I+D en las pymes: Intensidad y estrategia, Universia Business Review-Actualidad Económica, Primer trimestre, pp.43-47.

Barrand, J. and Goy, H. (2005) Les apports de la prospective aux approches cognitives de la stratégie en PME, Revue Internationale PME, Vol. 18, No. 2, pp.109-139.

Bessant, J. and Tidd, J. (2007) Innovation and Entrepreneurship, John Wiley \& Sons, USA.

Cohen, W.M. and Levinthal, D.A. (1990) 'Innovation and learning: two faces of R\&D', The Economic Journal, Vol. 99, No. 397, pp.569-596.

De Jong, J.P.J. (2011) 'Perceived competition and innovative intentions in Dutch small and medium-sized enterprises', International Journal of Innovation Management, Vol. 15, No. 4, pp.687-707.

De Sainté-Marie, G. (1999) Dirigir una PYME, 10 etapas, Paidós, Buenos Aires, Argentina.

De Sarbo, W.S., Di Benedetto, C.A., Song, N. and Sinha, I. (2005) 'Revisiting the Miles and Snow strategic framework: uncovering interrelationships between strategic types, capabilities, environmental uncertainty, and firm performance', Strategic Management Journal, Vol. 26, No. 1, pp.47-74.

Dussel, E. (2001) Claroscuros Integración exitosa de las pequeñas empresas y medianas empresas en México, Jus. Mexico.

Dvir, D., Segev, E. and Shenhar, A. (1993) 'Technology's varying impact on the success of strategic business units within the Miles and Snow typology', Strategic Management Journal, Vol. 14, No. 2, pp.155-162.

Estrada, R., Sánchez, V. and Hernández, M. (2011) Planeación estratégica e innovación en la PYME, Ponencia presentada al $2^{\circ}$ Congreso Internacional en México sobre la Micro, Pequeña y Mediana Empresa, Guadalajara, Jal.

Foreman-Peck, J., Makepeace, G. and Morgan, B. (2006) 'Growth and profitability of small and medium-sized enterprises: some Welsh evidence', Regional Studies, Vol. 40, No. 4, pp.307-319.

Freeman, C. (1974) The Economics of Industrial Innovation, Penguin Modern Economic Texts, London.

Gómez Mejía, L.R., Balkin, D.B. and Candy, R.L. (1998) Gestión de recursos humanos, Prentice Hall, Madrid.

Hambrick, D.C. (2003) 'On the staying power of defenders, analyzers, and prospectors', Academy of Management Executive, Vol. 17, No. 4, pp.115-118.

Henderson, M.R. and Clark, K.B. (1990) 'Architectural innovation: the reconfiguration of existing product technologies and the failure of established firms', Administrative Science Quarterly, Vol. 35, No. 1, pp.9-30.

Hudson, M., Smart, A. and Bourne, M. (2001) 'Theory and practice in SME performance measurement systems', International Journal of Operations and Production Management, Vol. 21, No. 8, pp.1096-1115.

INEGI (2004) Censos Economicos, Mexico.

Jonash, R.S. and Somerlatte, T. (1990) The Innovation Premium. How Next Generation Companies are Achieving Peak Performance and Profitability, Perseus Books, Reading, MA. 
Kabanoff, B. and Brown, S. (2008) 'Knowledge structures of prospectors, analyzers and defenders: content, structure, stability, and performance', Strategic Management Journal, Vol. 29, No. 2, pp.149-171.

Kotler, P., Armstrong, G., Saunders, J. and Wong, V. (2001) Principles of Marketing, Prentice Hall, London.

Lawlor, J. and Kavanagh, D. (2009) 'The relationship between new technologies and strategic activities', Technology Analysis \& Strategic Management, Vol. 21, No. 5, pp.587-598.

Madrid-Guijarro, A., García, D. and Van Auken, H. (2009) 'Barriers to innovation among Spanish manufacturing SMEs', Journal of Small Business Management, Vol. 47, No. 4, pp.465-488.

Méndez, R. (1999) Innovación tecnológica y reorganización del espacio industrial: una propuesta metodológica, EURE, Vol. XXIV, No. 73, pp.31-54.

Méndez, R. and Alonso, J.L. (2002) Sistemas locales de empresas y redes de innovación en Castilla la Mancha y Castilla-León, Universidad de Salamanca, Salamanca.

Miles, R.E. and Snow, C.C. (1978) Organizational Strategy, Structure and Process, McGraw-Hill, New York.

Miller, W.L. (2001) 'Innovation for business growth', Research Technology Management, Vol. 44, No. 5, pp.26-41.

OECD (2005) Oslo Manual, OECD Publications, Paris.

Pittino, D. and Visintin, F. (2009) 'Innovation and strategic types of family SMEs. A test and extension of Miles and Snow's configurational model', Journal of Enterprising Culture, Vol. 17, No. 3, pp.257-295.

Porter, M.E. (1980) Competitive Strategy. Techniques for Analyzing Industries and Competitors, The Free Press, New York.

Prahalad, C.K. and Hamel, G. (1990) 'The core competence of the corporation', Harvard Business Review, Vol. 68, No. 3, pp.79-87.

Rouse, M.J. and Daellenbach, U.S. (2002) 'More thinking on research methods for the resourcebased perspective', Strategic Management Journal, Vol. 23, No. 10, pp.963-967.

Saa, P.P. and Díaz, D.N.L. (2007) Incidencias de los Recursos humanos de I+D internos y contratados en la innovación, Cuadernos de Economía y Dirección de Empresas, Vol. 10, No. 33, pp.7-30.

Saavedra, M., Hernández, M., Mendoza, J., Hernández, Y., Jiménez, M., Navarrete, D. and Vazquez, A. (2007) Perfil Financiero y Administrativo de las Pequeñas y Medianas Empresas del Estado de Hidalgo, Universidad Autónoma del Estado de Hidalgo, México.

Salazar, E., Martín de Castro G. and López P. (2006) 'Capital intelectual. Una propuesta para clasificarlo y medirlo. Academia’, Revista Latinoamericana de Administración, Vol. 37, pp.1-16.

Sánchez, P. and Chaminade, C. (1996) Tecnología, productividad y empleo, IADE Research Paper No. 50.

Singh, V. and Sharma, R.R.K. (2010) 'Relating critical success factors of information system implementation with organizational strategy', International Journal of Business Strategy, Vol. 10, No. 2, pp.119-123.

Song, M., Im, S., Bij, H.V.D. and Song, L.Z. (2011) 'Does strategic planning enhance or impede innovation and firm performance?', Journal of Product Innovation Management, Vol. 28, No. 4, pp.503-520.

Tan, J., Fischer, E., Mitchell, R. and Phan, P. (2009) 'At the center or the action: innovation and technology strategy research in the small business setting', Journal of Small Business Management, Vol. 47, No. 3, pp.233-262.

Terziovski, M. (2010) 'Innovation practice and its performance implications in small and medium enterprises (SMEs) in the manufacturing sector: a resource-based view', Strategic Management Journal, Vol. 31, No. 8, pp.892-902.

Timens L., Boer, H. and Acur, N. (2006) 'The new product development improvement motives and practices of Miles and Snow's prospectors, analyzers and defenders', Journal Compilation, Vol. 15, No. 1, pp.85-95. 